\title{
Emergent Macrophytes Alter the Sediment Composition in a Small, Shallow Subtropical Lake: Implications for Methane Emission
}

\author{
Claudio Cardoso Marinho1*, Cleber Palma-Silva², Edélti Faria Albertoni2, \\ Iara Bueno Giacomini2 ${ }^{2}$, Marcos Paulo Figueiredo Barros ${ }^{3}$, Leonardo Marques Furlanetto², \\ Francisco de Assis Esteves ${ }^{3}$ \\ ${ }^{1}$ Laboratório de Limnologia, Departamento de Biologia, Universidade Federal do Rio de Janeiro, Rio de Janeiro, \\ Brasil \\ ${ }^{2}$ Laboratório de Limnologia, Instituto de Ciências Biológicas, Universidade Federal do Rio Grande-FURG, \\ Rio Grande, Brasil \\ ${ }^{3}$ NUPEM-Universidade Federal do Rio de Janeiro, Macaé, Brasil \\ Email: ${ }^{*}$ clcamar@biologia.ufri.br
}

Received 31 December 2014; accepted 7 February 2015; published 10 February 2015

Copyright (C) 2015 by authors and Scientific Research Publishing Inc.

This work is licensed under the Creative Commons Attribution International License (CC BY).

http://creativecommons.org/licenses/by/4.0/

(c) (i) Open Access

\begin{abstract}
Aquatic macrophytes in shallow lakes emit high levels of methane. We hypothesize that the presence of emergent aquatic macrophytes in an artificial shallow lake promotes important input of autochthonous organic matter (OM) in sediment and higher levels of methane emission via bubbles. Samplings were performed at three sites in a small, shallow subtropical lake: (1) one station in the limnetic region and (2) - (3) two stations in the littoral region ((2) inside and (3) outside aquatic macrophyte stands). A higher concentration of $\mathrm{OM}$ was observed at the macrophyte station, and within this site, a higher methane concentration was observed in the sediment. These results could explain the methane ebullition values at macrophyte sites. At the macrophyte station, methane emission via bubbles contributed $17 \%$ to $56 \%$ of the total methane emission; however, at the other stations, its contribution via bubbles, was lower than $1 \%$. This research confirmed the importance of emergent macrophytes at Polegar Lake as a source of $\mathrm{OM}$ in sediment and methane emission via bubbles. Further, we could confirm the positive effects of temperature on methane emission, mainly by bubbles.
\end{abstract}

\section{Keywords}

Methane Emission, Shallow Lakes, Greenhouse Gases, Global Warming

\footnotetext{
${ }^{*}$ Corresponding author.
}

How to cite this paper: Marinho, C.C., et al. (2015) Emergent Macrophytes Alter the Sediment Composition in a Small, Shallow Subtropical Lake: Implications for Methane Emission. American Journal of Plant Sciences, 6, 315-322. 


\section{Introduction}

Methane emissions from global freshwater systems represent a significant contribution to the global balance of greenhouse gases [1]. These ecosystems are the largest natural source of methane emissions to the atmosphere, contributing up to one-third of global emissions [1]. This gas is formed under anoxic conditions in the sediments of flooded areas [3] by a process termed methanogenesis. The emission of methane into the atmosphere is the net result of methanogenesis and methane oxidation.

Methanogenesis depends on interactions between several factors, such as sediment characteristics, electron acceptor concentrations, environmental conditions and aquatic macrophyte properties [4]. Biological methane oxidation, known as methanotrophy, may oxidize 30\% - 99\% of methane produced in freshwater systems [5] and is important in the regulation of methane emissions in freshwater. In general, a high level of methane oxidation occurs under aerobic conditions; however, this process can also occur under anaerobic conditions. These processes, mainly methanogenesis, may be regulated by temperature [6]. Several environments indicate that methanogenesis in sediments is highly sensitive to temperature [7]-[9]. Studies on methane dynamics in shallow lakes in southern Brazil have shown that a variation of almost $10^{\circ} \mathrm{C}$ between sampling periods was positively related to the concentration of methane, indicating the importance of seasonality, mainly in an oligo-mesotrophic environment [10].

Methane emissions are also influenced by temperature, which is an important factor considering bubble emissions, mainly in shallow environments with lower hydrostatic pressure [11] [12]. In addition, recent estimates of the global number of lakes [13] indicate the great importance of small lakes for methane emission. These ecosystems present higher methane fluxes per unit area than larger lakes [14].

Many of the wetlands have populations of emergent plants that were either deliberately planted or naturally colonized the area [15]. The presence of macrophytes can modify sediment composition via the accumulation of detritus [16], which is refractory in nature [17]. These plants are morphologically adapted to grow in anoxic sediments; for example, they develop aerenchyma tissue that supplies their roots with $\mathrm{O}_{2}$. However, this aerenchyma can also act as a conduit for methane, thereby increasing the flux of these gases from the sediment to the atmosphere. With a higher vegetation density, almost all methane enters the atmosphere through plants [18]. Therefore, stands of aquatic macrophytes affect three processes by 1) allocation of below-ground labile organic material through root exudation and plant litter production, thereby supporting methanogenesis [19] [20]; 2) input of atmospheric $\mathrm{O}_{2}$ to the rhizosphere fueling methane oxidation [21]; and 3) by acting as a conduit, allowing methane to "escape" the system [22] and minimizing the oxidation process.

The hypothesis of this study is that the presence of emergent aquatic macrophytes in an artificial shallow lake promotes important input of autochthonous organic matter (OM) for sediment and higher methane emission via bubbles.

\section{Materials and Methods}

\subsection{Study Area}

Polegar Lake (32 $01^{\prime} 40^{\prime} \mathrm{S}, 52^{\circ} 05^{\prime} 40^{\prime \prime} \mathrm{W}$ ) is located at the sandy coastal plain of Rio Grande do Sul (Southern Brazil), municipality of Rio Grande, that mainly comprises wetlands and small, shallow lakes. The climate of this region is characterized as Cfa (humid subtropical) by the Köppen classification. Polegar Lake was constructed approximately sixteen years ago. This lake has an area of approximately $1 \mathrm{ha}$, with an average depth of $1.5 \mathrm{~m}$, and the depth varies depending on rainfall amounts. It is characterized as an oligo-mesotrophic lake with low primary production and low nutrient concentration [10] [23]. Its shallow depth and wind action characterize it as polymictic. The sediment is sandy and contains a low concentration of nutrients and OM [24]. An emergent aquatic macrophyte, Schoenoplectus californicus, occupies approximately $10 \%$ of the area of Polegar Lake near its margins.

\subsection{Sampling}

Samplings were carried out in summer (February), fall (May), winter (July) and spring (September) of 2007 at three sampling sites. One sampling station was in the limnetic region, and two stations were in the littoral region. Of the two littoral stations, one was inside and one was outside aquatic macrophyte stands; thus, the three sampling stations were classified as 1) limnetic, 2) littoral and 3) macrophyte. 
During the summer, methane and OM concentration in the sediment were sampled. These evaluations were performed to characterize the composition and anaerobic metabolism of the sediment. In the summer, the other variables were not sampled because during this period, the macrophyte station of Polegar Lake was dry. Samples were obtained for four consecutive days. The sampling process consisted of setting up a system that collected the bubbles of methane released from the sediment, water samples to evaluate methane concentrations and abiotic variables at each sampling point.

\subsection{Variable Measurements}

The bubble collection system was composed of an inverted funnel $(24 \mathrm{~cm}$ diameter) with a glass flask attached at the posterior part of the opening. This system was placed in situ for $24 \mathrm{~h} \mathrm{[25].} \mathrm{After} 24 \mathrm{~h}$, the tubes were collected, replaced, and stored inverted with water in contact with the rubber cap. All samples were transported to the laboratory in a cool box for gas composition analysis. For determining the methane concentration in the water column, $8 \mathrm{~mL}$ of water was collected in situ with a syringe and injected into a $12 \mathrm{~mL}$ sealed glass flask with negative pressure in its interior containing $1.6 \mathrm{~g}$ of $\mathrm{NaCl}$. Diffusive flux $(\mathrm{F})$ was estimated using the following expression: $\mathrm{F}=\mathrm{KCH}_{4}(\mathrm{Cw}$-Ceq) [26]. This expression describes the use of a two-layer model to estimate the flux of various gases across the air-water interface, where $\mathrm{KCH}_{4}$ indicates the piston velocities for methane at each water temperature, $\mathrm{Cw}$ indicates the concentration of dissolved methane at the lake surface and Ceq indicates the concentration of methane in water-air equilibrium.

For determining the concentration of methane in sediment $\left(\left[\mathrm{CH}_{4}\right]_{\mathrm{sed}}\right)$, the sediment was sampled with a core (8 $\mathrm{cm}$ internal diameter and $50 \mathrm{~cm}$ length) attached to a Kajak sediment sampler. Five cores were obtained at each sampling point, and only the uppermost layer $(2 \mathrm{~cm})$ was considered. In the field, $5 \mathrm{~mL}$ of sediment was placed in $25 \mathrm{~mL}$ glass vials $(\mathrm{n}=5)$ containing $5 \mathrm{~mL}$ of concentrated $\mathrm{NaCl}$ solution to expel methane contained in the sediment. The vials were sealed and transported to the laboratory, where $1 \mathrm{~mL}$ of the headspace of the bottle was removed with a syringe to determine the methane concentration by gas chromatography. The same sample fractions used to determine the methane concentration were used to evaluate OM after drying in the laboratory. OM in sediment was determined by the gravimetric method after ignition at $550^{\circ} \mathrm{C}$ for 4 hours. The environmental variables measured in the water column were temperature and dissolved oxygen (Oakton DO 300 oxygen meter), pH (Hanna HI 8314 pH meter) and depth (ruler). The methane concentration in the headspace was determined by gas chromatography using a Varian Star 3400 (Varian Co., USA) gas chromatograph equipped with a flame ionization detector (FID) at $200^{\circ} \mathrm{C}$ and an injector at $120^{\circ} \mathrm{C}$ along with a Poropak-Q $1 \mathrm{~m}$ (60/100 mesh) column $\left(65^{\circ} \mathrm{C}\right)$ with $\mathrm{N}_{2}$ as a carrier gas.

\subsection{Statistical Analysis}

The methane concentration measurements in the sediment and OM were analyzed using ANOVA and Tukey's post-test. The methane ebullition and diffusive emission measurements were analyzed using the Kruskal-Wallis test, Dunn's post-hoc test and the Mann-Whitney test. The significance level was set at $95 \%$. The tests were performed using Graph Pad Instat 3.0 (Graph Pad Software Co.).

\section{Results and Discussion}

The concentrations of OM in sediment presented significant $(\mathrm{p}<0.05)$ spatial differences (Table 1), with higher values observed at the macrophyte station. This difference occurs due to the higher autochthonous OM input via macrophyte detritus. Aquatic plant detritus accumulates heavily over sediments of shallow aquatic ecosystems and may be the main source of $\mathrm{CH}_{4}$ emissions [27] [28]. Detritus of emergent macrophytes strongly contributes to nutrient enrichment of the sediment [16]. The higher OM concentrations in sediment at sites colonized by emergent macrophytes result from the high productivity rates in these compartments [29]. These high rates are associated with slow debris transport to other compartments in lentic systems and slow decomposition rates. Decomposition rates largely depend on the composition of macrophyte tissues. Emergent macrophytes have the highest amounts of structural tissues compared with other functional groups [17]. All these factors favor the accumulation of $\mathrm{OM}$ in the sediment over time in the littoral region, which is beneficial for decomposers [16]. Lower OM concentrations were observed in the littoral station (without macrophytes). These results may be due to the presence of small holes in the sediment of the limnetic station. These holes accumulate OM, producing a 
Table 1. Concentration of methane $\left(\left[\mathrm{CH}_{4}\right]_{\mathrm{sed}}\right)$ and organic matter $(\mathrm{OM})$ in the sediment of Polegar Lake in summer (February 2007).

\begin{tabular}{cccc}
\hline Variables & \multicolumn{3}{c}{ Station } \\
\cline { 2 - 4 } & Limnetic & Littoral & Macrophyte \\
\hline $\begin{array}{c}\text { Methane in sediment } \\
(\mu \mathrm{M} \text { in pore water }) \\
\text { Organic matter } \\
(\% \mathrm{DW})\end{array}$ & $380 \pm 174$ & $7.53 \pm 3.56$ & $483 \pm 183$ \\
\hline
\end{tabular}

Mean \pm standard deviation.

heterogeneous sediment, as evidenced by the higher standard deviation at this station (Table 1). These alterations in the sediment can cause variations in macrophyte cover in aquatic ecosystems [30], which can determine the distribution of this community in aquatic ecosystems.

Methane concentrations in the water column varied between minimum values of $0.30 \pm 0.02 \mu \mathrm{M}$ and maximum values of $1.92 \pm 0.1 \mu \mathrm{M}$ (Table 2). Methane was always supersaturated at the surface of Polegar Lake. This indicates that methane fluxes values were always positive; i.e., methane flowed from the water column to the atmosphere. The higher methane concentrations in the water column observed in spring were significantly (p $<0.05$ ) higher than those observed in winter (Table 2). This result suggests that temperature has effects on methanogenesis (Table 2), which agrees with the literature [6] [8]. The same pattern was observed in samplings performed at the Polegar Lake in 2001 and 2002 [10], in which methane concentrations in the water column were also higher in spring compared to winter. Furthermore, we can observe a trophic state change in Polegar Lake, from oligotrophic to mesotrophic. Eutrophication of aquatic ecosystems enhances methanogenesis [31], which can explain the observed increase in the methane concentration of the water column in Polegar Lake: 0.19 $\mu \mathrm{M}$ in July 2002 to $0.30 \mu \mathrm{M}$ in July 2007. The water temperatures were similar at these time points (approximately $13^{\circ} \mathrm{C}$ ).

The methane concentration in the water column was not significantly different ( $\mathrm{p}>0.05$ ) among the sampling stations, and the same pattern was observed in the diffusive methane emission. Shallow aquatic ecosystems present a highly mixed water mass due to the low water column. This finding indicates that methane released from the sediment into the water column (via diffusive processes) can be transported laterally from stations with higher methane concentrations in the sediment to the stations with low methane concentrations in the sediment. Total methane emission from Polegar Lake includes both diffusive and ebullitive emission. The total methane emission measured was highly variable and ranged from $4436 \mu \mathrm{mol} \cdot \mathrm{m}^{-2} \cdot \mathrm{d}^{-1}$ to $131 \mu \mathrm{mol} \cdot \mathrm{m}^{-2} \cdot \mathrm{d}^{-1}$ (Table 2). In general, diffusive emission accounted for an average of $72 \%$ of the total emission. The values measured at Polegar Lake are similar to those measured at other shallow ecosystems. According to [32], in shallow coastal lagoons of the Ivory Coast (West Africa), diffusive air-water $\mathrm{CH}_{4}$ fluxes ranged between 20 and 2403 $\mu \mathrm{mol} \cdot \mathrm{m}^{-2} \cdot \mathrm{d}^{-1}$. In limnetic and littoral stations, diffusive emission accounted for $99 \%$ of the total emission (Table 3 ), whereas at the macrophyte station, the contribution of methane ebullition varied from $17 \%$ to $56 \%$ (Table 3 ). These results confirm the importance of temperature and the presence of emergent macrophytes for methane emission in aquatic ecosystems, which can be confirmed by methane emission via bubbles (Table 2). Methane emission via bubbles in shallow aquatic ecosystems is very important due to its major effects on the methane oxidation process in the water column. When crossing the water column, methane bubbles have little or no influence on methanotrophic bacteria. Further, it is important to highlight the participation of emergent macrophytes in methane emission via their aerenchyma. This mechanism may be responsible for up to $90 \%$ of methane emission [33].

The results of the current study can be explained because the accumulation of macrophyte detritus alters not only sediment composition but also biological activity—mainly anaerobic processes such as methanogenesis [28] [34]. This can be confirmed by the methane concentration in the sediment (Table 1). Macrophyte OM accumulated in the sediment (via detritus) contributes to the supply of OM through substrate production (such as acetate and $\mathrm{CO}_{2} / \mathrm{H}_{2}$ ) via decomposition processes, thus supporting methanogenesis [35]. In addition, methane production also can be linked to labile carbon via root exudates [36] [37], which can increase the consumption of oxygen and production of substrates for methanogenesis. These results corroborate those of other studies that also revealed high methane concentrations in sediment colonized by emergent macrophytes [34] [38]-[40]. 
Table 2. Abiotic variables in the water column at Polegar Lake and air temperature. Sampling was performed in autumn (May), winter (July) and spring (September) of 2007 at the limnetic, littoral and macrophyte stations. The variables sampled were methane concentration ([CH 4$)$, dissolved oxygen (DO), air temperature ( $\mathrm{T}$ air), water temperature ( $\mathrm{T}$ water), $\mathrm{pH}$, conductivity (Cond) and depth.

\begin{tabular}{ccccccccc}
\hline Date & Station & {$\left[\mathrm{CH}_{4}\right]$} & $\mathrm{DO}$ & $\mathrm{T}$ air & T water & $\mathrm{pH}$ & Cond & Depth \\
\hline \multirow{2}{*}{ Autumn } & Limnetic & $0.50 \pm 0.2$ & $8.2 \pm 0.4$ & $13 \pm 4$ & $15 \pm 2$ & $6.7 \pm 0.4$ & $101 \pm 3$ & $0.9 \pm 0.1$ \\
& Littoral & $0.63 \pm 0.2$ & $8.3 \pm 0.3$ & $16.9 \pm 2$ & $14.6 \pm 2$ & $6.5 \pm 0.3$ & $101 \pm 0.8$ & $0.7 \pm 0.1$ \\
& Macrophyte & $0.95 \pm 0.5$ & $8.2 \pm 0.4$ & $14.3 \pm 4$ & $14.8 \pm 2$ & $6.6 \pm 0.1$ & $101 \pm 0.3$ & $0.8 \pm 0.1$ \\
& Limnetic & $0.31 \pm 0.1$ & $9.2 \pm 0.4$ & $16.2 \pm 2$ & $13.6 \pm 1$ & $6.9 \pm 0.5$ & $70 \pm 0.3$ & $1.4 \pm 0$ \\
\multirow{3}{*}{ Winter } & Littoral & $0.30 \pm 0.02$ & $9.4 \pm 0.2$ & $16.2 \pm 2$ & $13.1 \pm 0.3$ & $6.6 \pm 0.5$ & $71 \pm 2$ & $1.3 \pm 0.1$ \\
& Macrophyte & $0.36 \pm 0.1$ & $9.2 \pm 0.3$ & $16.3 \pm 2$ & $13.4 \pm 0.3$ & $6.8 \pm 0.1$ & $68 \pm 1$ & $1 . \pm \pm 0.2$ \\
& Limnetic & $1.72 \pm 0.4$ & $10.2 \pm 0.8$ & $18.6 \pm 0.6$ & $17 \pm 0.9$ & $6.9 \pm 0.4$ & $58 \pm 2$ & $1.3 \pm 0.1$ \\
& Littoral & $1.42 \pm 0.4$ & $9.1 \pm 0.3$ & $19 \pm 0$ & $16.9 \pm 1$ & $6.5 \pm 0.2$ & $59 \pm 2$ & $1.2 \pm 0.2$ \\
& Macrophyte & $1.92 \pm 0.1$ & $9.4 \pm 0.8$ & $19 \pm 0$ & $17.1 \pm 1.5$ & $6.5 \pm 0.3$ & $59 \pm 0.7$ & $1 \pm 0.2$ \\
\hline
\end{tabular}

Mean \pm standard deviation.

Table 3. Methane emission by diffusive and ebullient processes. The total methane emission was obtained by the sum of these two processes. Sampling was performed in May, July and September of 2007 at the limnetic, littoral and macrophyte stations.

\begin{tabular}{|c|c|c|c|c|}
\hline \multirow{3}{*}{ Date } & & \multicolumn{3}{|c|}{ Station } \\
\hline & & Limnetic & Littoral & Macrophyte \\
\hline & & \multicolumn{3}{|c|}{$\mu \mathrm{mol} \cdot \mathrm{m}^{-2} \cdot$ day $^{-1}$} \\
\hline \multirow[t]{3}{*}{ Autumn } & Ebullient & $1.44 \pm 1.57$ & $0.20 \pm 0.04$ & $162 \pm 139$ \\
\hline & Diffusive & $372 \pm 45$ & $491 \pm 90$ & $780 \pm 216$ \\
\hline & Total & 373 & 492 & 942 \\
\hline \multirow[t]{3}{*}{ Winter } & Ebullient & $0.17 \pm 0.13$ & $0.12 \pm 0.04$ & $80 \pm 17$ \\
\hline & Diffusive & $139 \pm 40$ & $131 \pm 11$ & $163 \pm 59$ \\
\hline & Total & 139 & 131 & 243 \\
\hline \multirow[t]{3}{*}{ Spring } & Ebullient & $12 \pm 18$ & $2.2 \pm 1.05$ & $2498 \pm 1068$ \\
\hline & Diffusive & $1673 \pm 534$ & $1472 \pm 462$ & $1938 \pm 762$ \\
\hline & Total & 1685 & 1474 & 4436 \\
\hline
\end{tabular}

Mean \pm standard deviation.

However, the presence of emergent macrophytes can also inhibit methanogenesis via the oxidation of sediment. During this process, there is an input of atmospheric oxygen to the rhizosphere, which can also increase methane oxidation [33] [41] due to the high concentration of methane and oxygen in this microcosm. This process can explain the high methane concentrations in sediment at the limnetic station (Table 1) despite its lower OM concentration when compared to the macrophyte station (Table 1). At the limnetic station, which lacks macrophytes but has a higher concentration of OM in sediment compared with the littoral station, the methane oxidation process might make a smaller contribution than it does at the macrophyte station. In sediment colonized by macrophytes, the autotrophic activity of this community can both explain the inhibition of methane production and favor methane oxidation. In temperate shallow aquatic systems, studies with macrophytes suggest that progressively higher amounts of oxygen are transferred to roots in the winter-summer shift [42]. This 
finding can explain the higher contribution of methane emission by bubbles during the winter period, when lower temperatures were observed in the present study, in relation to the diffusive process.

\section{Conclusion}

Our hypotheses were accepted because we concluded that emergent macrophytes at Polegar Lake, including Schoenoplectus californicus as a dominant species, were very important for 1) OM input to sediment and anaerobic activity of this compartment and 2) methane emission via bubbles in this aquatic ecosystem. Further, we could confirm the positive effects of temperature on methane emission, mainly via bubbles.

\section{Acknowledgements}

The authors are grateful to CAPES and CNPq for financial support. Adriana de Melo Rocha assisted with language editing of the English language version of the manuscript.

\section{References}

[1] Bastviken, D., Tranvik, L.J., Downing, J.A., Crill, P.M. and Enrich-Prast, A. (2011) Freshwater Methane Emissions Offset the Continental Carbon Sink. Science, 331, 50. http://dx.doi.org/10.1126/science.1196808

[2] Solomon, S., Quin, D. and Manning, M., Eds. (2007) IPCC. Fourth Assessment Report-Climate Change 2007. The Physical Science Basic Cambridge University Press, New York.

[3] Conrad, R. (1989) Control of Methane Production in Terrestrial Ecosystems. In: Andreae, M.O. and Schimel, D.S., Eds., Exchange of Trce Gases between Terrestrial Ecosystems and the Atmosphere, Wiley, Chichester, 39-58.

[4] Reddy, K.R. and Delaune, R.D. (2008) Biogeochemistry of Wetlands: Science and Applications. CRC Press, Boca Raton. http://dx.doi.org/10.1201/9780203491454

[5] Bastviken, D., Cole, J.J., Pace, M.L. and van de Bogert, M. (2008) The Fates of Methane from Different Lake Habitats-Connecting Whole Lake Budgets and $\mathrm{CH}_{4}$ Emissions. Journal of Geophysical Research, 113, Article No. G02024.

[6] Inglett, K.S., Inglett, P.W., Reddy, K.R. and Osborne, T.Z. (2011) Temperatue Sensitivity of Greenhouse Gas Production in Wetland Solis of Different Vegetattion. Biogeochemistry, 108, 77-90. http://dx.doi.org/10.1007/s10533-011-9573-3

[7] Furtado, A.L.S. and Casper, P. (2000). Factors Influencing Methane Production in an Oligotrophic and in a Eutrophic German Lake. Verhandlungen der Internationalen Vereinigung für Theoretische und Angewandte Limnologie, 27, 1441-1445.

[8] Fierer, N., Craine, J.M., Mclauchlan, K. and Schimed, J.P. (2005) Litter Quality and the Temperature Sensitivity of Decomposition. Ecology, 86, 320-326. http://dx.doi.org/10.1890/04-1254

[9] Duc, N.T., Crill, P. and Bastivken, D. (2010) Implications of Temperature and Sediment Characteristics on Methane Formation and Oxidation in Lake Sediments. Biogeochemistry, 100, 185-196. http://dx.doi.org/10.1007/s10533-010-9415-8

[10] Marinho, C.C., Palma Silva, C., Albertoni, E.C., Trindade, C.R. and Esteves, F.A. (2009) Seasonal Dynamics of Methane in the Water Column of Two Subtropical Lakes Differing in Trophic Status. Brazilian Journal of Biology, 69, 281-287. http://dx.doi.org/10.1590/S1519-69842009000200007

[11] Bastviken, D., Cole, J., Pace, M. and Tranvik, L. (2004) Methane Emissions from Lakes: Dependence of Lake Characteristics, Two Regional Assessments, and a Global Estimate. Global Biogeochemical Cycles, 18, No. 4. http://dx.doi.org/10.1029/2004GB002238

[12] Palma-Silva, C., Marinho, C.C., Albertoni, E.F., Giacomini, I.B., Barros, M.P.F., Furlaneto, L.M., Trindade, C.R. and Esteves, F.A. (2013) Methane Emissions in Two Small Shallow Neotropical Lakes: The Role of Temperature and Trophic Level. Atmospheric Environment, 81, 373-379. http://dx.doi.org/10.1016/j.atmosenv.2013.09.029

[13] Downing, J.A., Prairie, Y.T., Cole, J.J., Duarte, C.M., Tranvik, L.J., Striegl, R.G., McDowell, W.H., Kortelainen, P., Caraco, N.F., Melack, J.M. and Middelburg, J.J. (2006) The Global Abundance and Size Distribution of Lakes, Ponds, and Impoundments. Limnology and Oceanography, 51, 2388-2397. http://dx.doi.org/10.4319/lo.2006.51.5.2388

[14] Juutinen, S., Rantakari, M., Kortelainen, P., Huttunen, J.T., Larmola, T., Alm, J., Silvola, J. and Martikainen, P.J. (2009) Methane Dynamics in Different Boreal Lake Types. Biogeosciences, 6, 209-223. http://dx.doi.org/10.5194/bg-6-209-2009

[15] Bendrix, M., Tornberge, T. and Brix, H. (1994) Internal Gas Transport in Typha latifolia L. and Typha angustifolia L. Humidity-Induced Pressurization and Convective Through-Flow. Aquatic Botany, 49, 75-89. http://dx.doi.org/10.1016/0304-3770(94)90030-2 
[16] Marinho, C.C., Meireles-Pereira, F., Gripp, A.R., Guimaraes, C.C., Esteves, F.A. and Bozelli, R.L. (2010) Aquatic Macrophytes Drive Sediment Stoichiometry and the Suspended Particulate Organic Carbon Composition of a Tropical Coastal Lagoon. Acta Limnologica Brasiliensia, 22, 208-217. http://dx.doi.org/10.1590/S2179-975X2010000200010

[17] Farjalla, V.F., Marinho, C.C. and Esteves, F.A. (1999) Uptake of Oxygen in the Initial Stages of Decomposition of Aquatic Macrophytes and Detritus from Terrestrial Vegetation in a Tropical Coastal Lagoon. Acta Limnologica Brasiliensia, 11, 185-193.

[18] Bazhim, N.M. (2004) Influence of Plants on the Methane Emission from Sediments. Chemosphere, 54, 209-215. http://dx.doi.org/10.1016/S0045-6535(03)00571-X

[19] Ding, W., Cai, Z., Tsuruta, H. and Li, X. (2002) Effect of Standing Water Depth on Methane Emission from Freshwater Marshes in Northeast China. Atmospheric Environment, 36, 5149-5157.

[20] King, J.Y. and Reeburgh, W.S. (2002) A Pulse-Labeling Experiment to Determine the Contribution of Recent Plant Photosynthates to Net Methane Emission in Arctic Wet Sedge Tundra. Soil Biology Biochemistry, 34, 173-180. http://dx.doi.org/10.1016/S0038-0717(01)00164-X

[21] King, G.M. (1994) Associations of Methanotrophs with the Roots and Rhizomes of Aquatic Vegetation. Applied and Environmental Microbiology, 60, 3220-3227.

[22] Hirotta, M., Tang, Y., Hu, Q., Hirata, S., Kato, T., Mo, W., Cao, G. and Mariko, S. (2004) Methane Emission from Different Vegetation Zones in a Qinghai-Tbetan Plateau Wetland. Soil Biology and Biochemistry, 36, 737-748. http://dx.doi.org/10.1016/j.soilbio.2003.12.009

[23] Albertoni, E.F., Prellvitz, L.J. and Palma-Silva, C. (2007) Macroinvertebrate Fauna Associated with Pistiastratiotes and Nymphoidesindica in Subtropical Lakes (South Brazil). Brazilian Journal of Biology, 67, 499-507. http://dx.doi.org/10.1590/S1519-69842007000300015

[24] Furlanetto, L.M., Marinho, C.C., Palma-Silva, C., Albertoni, E.F., Figueiredo-Barros, M.P. and Esteves, F.A. (2012) Methane Levels in Shallow Subtropical Lake Sediments: Dependence on the Trophic Status of the Lake and Allochthonous Input. Limnologica, 42, 151-155. http://dx.doi.org/10.1016/j.limno.2011.09.009

[25] Casper, P., Maberly, S., Hall, G.H. and Finlay, B.J. (2000) Fluxes of Methane and Carbon Dioxide from a Small Productive Lake to the Atmosphere. Biogeochemistry, 49, 1-19. http://dx.doi.org/10.1023/A:1006269900174

[26] Liss, P.S. and Slater, P.G. (1974) Flux of Gases across the Air-Sea Interface. Nature, 247, 181-184. http://dx.doi.org/10.1038/247181a0

[27] Sutton-Grier, A.S. and Megonigal, J.P. (2011) Plant Species Traits Regulate Methane Production in Freshwater Wetland Soils. Soil Biology and Biochemistry, 43, 413-420. http://dx.doi.org/10.1016/j.soilbio.2010.11.009

[28] Laanbroek, H. (2010) Methane Emission from Natural Wetlands: Interplay between Emergent Macrophytes and Soil Microbial Processes. A Mini-Review. Annals of Botany, 105, 141-153. http://dx.doi.org/10.1093/aob/mcp201

[29] Wetzel, R.G. (1983) Limnology. 2nd Edition, Sounders College, Philadelphia, 860 p.

[30] Kisson, L.T.T., Jacob, D.L., Hanson, M.A., Herwig, B.R., Bowe, S.E. and Otte, M.L. (2013) Macrophytes in Shallow Lakes: Relationships with Water, Sediment and Watershed Characteristics. Aquatic Botany, 109, 39-48. http://dx.doi.org/10.1016/j.aquabot.2013.04.001

[31] Casper, P. (1992) Methane Production in Lakes of Different Trophic State. Archiv für Hydrobiologie-Beiheft Ergebnisse der Limnologie, 37, 149-154.

[32] Koné, Y.J.M., Abril, G., Delille, B. and Borges, A.V. (2010) Seasonal Variability of Methane in the Rivers and Lagoons of Ivory Coast (West Africa). Biogeochemistry, 100, 21-37. http://dx.doi.org/10.1007/s10533-009-9402-0

[33] van der Nat, F.J.W.A. and Middelburg, J.J. (1998) Effects of Two Common Macrophytes on Methane Dynamics in Freshwater Sediments. Biogeochemistry, 43, 79-104.

[34] Fonseca, A.L.S., Minello, M., Marinho, C.C. and Esteves, F.A. (2004) Methane Concentration in Water Column and in Pore Water of a Coastal Lagoon (Cabiúnas Lagoon, RJ, Brazil). Brazilian Archives of Biology and Technology, 47, 301-308. http://dx.doi.org/10.1590/S1516-89132004000200018

[35] Schulz, S. and Conrad, R. (1995) Effect of Algal Deposition on Acetate and Methane Concentrations in the Profundal Sediment of Deep Lake (Lake Constance). FEMS Microbiology Ecology, 16, 251-260. http://dx.doi.org/10.1111/j.1574-6941.1995.tb00289.x

[36] Kimura, M., Miura, Y., Watanabe, A., Katoh, T. and Haraguchi, H. (1991) Methane Emission from Paddy Field (Part 1) Effect of Fertilization, Growth Stage and Midsummer Drainage: Pot Experiment. Environmental Science, 4, 265-271.

[37] Whiting, G.J. and Chanton, J.P. (1992) Plant-Dependent $\mathrm{CH}_{4}$ Emission in a Subarctic Canadian Fen. Global Biogeochemical Cycles, 6, 225-231. http://dx.doi.org/10.1029/92GB00710

[38] Chan, O.C., Wolf, M., Hepperle, D. and Casper, P. (2002) Methanogenic Archaeal Community in the Sediment of an Artificially Partitioned Acidic Bog Lake. FEMS Microbiology Ecology, 42, 119-129. 
http://dx.doi.org/10.1111/j.1574-6941.2002.tb01001.x

[39] Bastviken, D., Santoro, A.L., Marotta, H., Pinho, L.Q., Calheiros, D.F., Crill, P. and Enrich-Prast, A. (2010) Methane Emissions from Pantanal, South America, during the Low Water Season: Toward More Comprehensive Sampling. Environmental Science Technology, 44, 5450-5455. http://dx.doi.org/10.1021/es1005048

[40] de Oliveira Santos Neves, J.M.C., Aragon, G.T. and Silva Filho, E.V. (2011) Effects of Eutrophication and Typha domingensis Pers on Methanogenesis in Tropical Constructed Wetland. Acta Limnologica Brasiliensia, 23, 145-153. http://dx.doi.org/10.1590/S2179-975X2011000200005

[41] Sorrell, B.K., Downes, M.T. and Stanger, C.L. (2002) Methanotrophic Bacteria and Their Activity on Submerged Aquatic Macrophytes. Aquatic Botany, 72, 107-119. http://dx.doi.org/10.1016/S0304-3770(01)00215-7

[42] Soana, E. and Bartoli, M. (2013) Seasonal Variation of Radial Oxygen Loss in Vallisneria spiralis L.: An Adaptive Response to Sediment Redox? Aquatic Botany, 104, 228-232. http://dx.doi.org/10.1016/j.aquabot.2012.07.007 
Scientific Research Publishing (SCIRP) is one of the largest Open Access journal publishers. It is currently publishing more than 200 open access, online, peer-reviewed journals covering a wide range of academic disciplines. SCIRP serves the worldwide academic communities and contributes to the progress and application of science with its publication.

Other selected journals from SCIRP are listed as below. Submit your manuscript to us via either submit@scirp.org or Online Submission Portal.
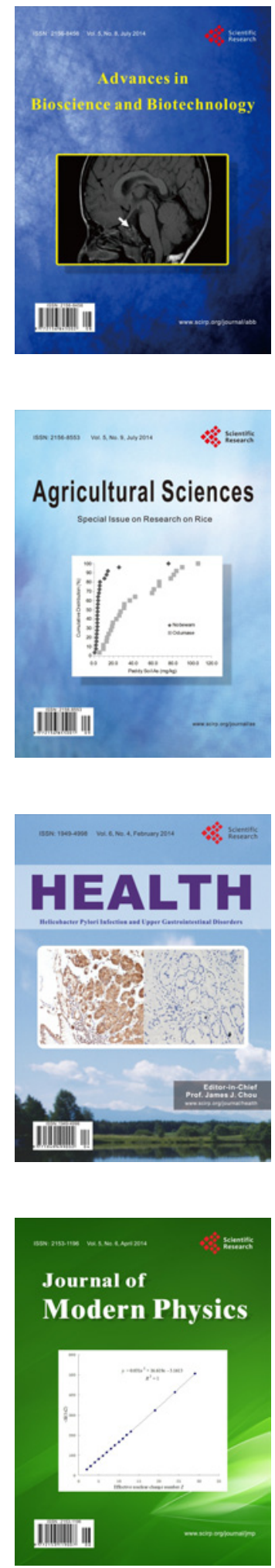
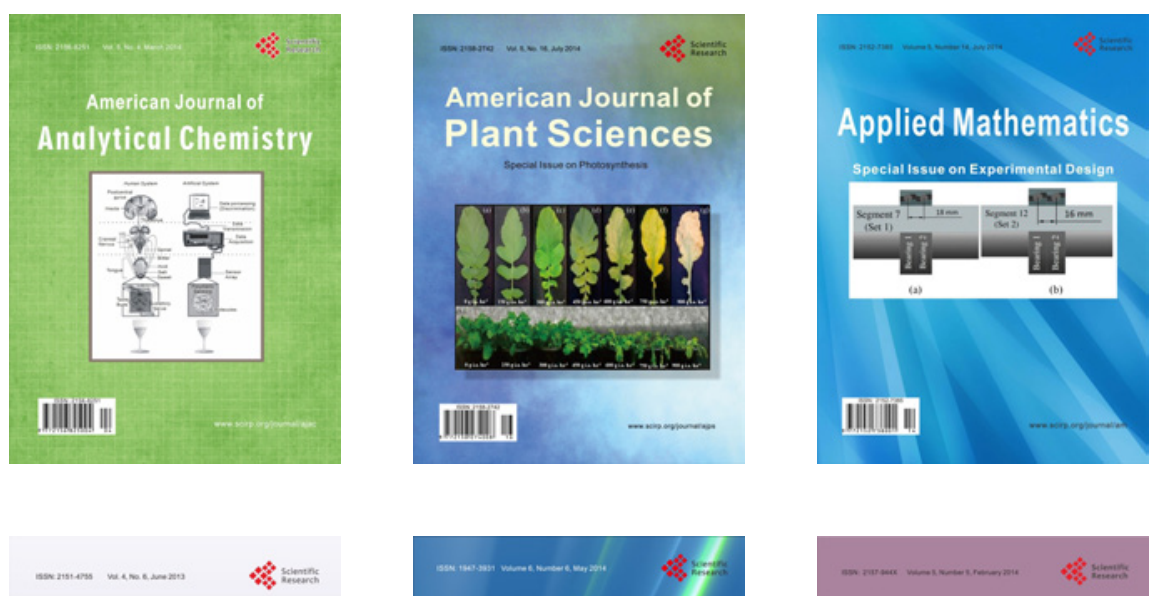

Creative Education
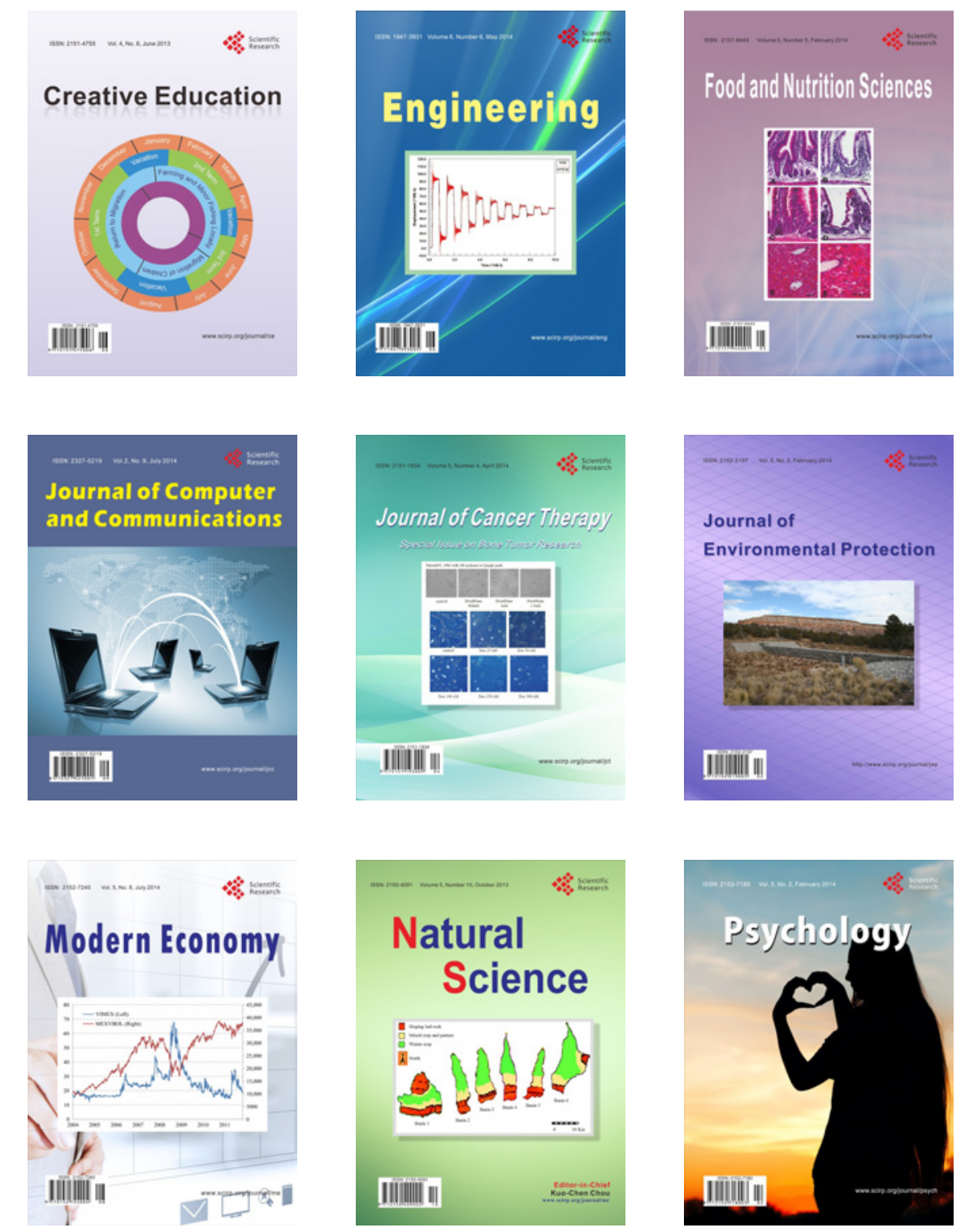